\title{
Fungal secretomics of ascomycete fungi for biotechnological applications
}

\section{Couturier $M^{1,2}$, Navarro $D^{1,2,3}$, Favel $A^{1,2,3}$, Haon $M^{1,2}$, Lechat $C^{4}$, Lesage-Meessen $L^{1,2}$, Chevret $D^{5}$, Lombard $V^{6}$, Henrissat $B^{6,7,8}$ and Berrin JG ${ }^{1,2}$}

${ }^{1}$ INRA, UMR1163 BBF, Polytech'Marseille, F-13288 Marseille, France

2Aix Marseille Université, UMR1163 BBF, Polytech'Marseille, F-13288 Marseille, France

${ }^{3}$ CIRM-CF, UMR1163 BBF, Polytech'Marseille, F-13288 Marseille, France

${ }^{4}$ ASCOFrance, Villiers-en-Bois, France

${ }^{5}$ INRA, UMR1319 Micalis, Plateforme d'Analyse Protéomique de Paris Sud-Ouest, Jouy-en-Josas, 78352, France

${ }^{6}$ Architecture et Fonction des Macromolécules Biologiques, UMR7257 CNRS, Aix-Marseille University, F-13288 Marseille, France

${ }^{7}$ INRA, USC1408 Architecture et Fonction des Macromolécules Biologiques, F-13288 Marseille, France

${ }^{8}$ Department of Biological Sciences, King Abdulaziz, University, Jeddah, Saudi Arabia

Couturier M, Navarro D, Favel A, Haon M, Lechat C, Lesage-Meessen L, Chevret D, Lombard V, Henrissat B, Berrin JG 2016 - Fungal secretomics of ascomycete fungi for biotechnological applications. Mycosphere 7(10), 1546-1553, Doi 10.5943/mycosphere/si/3b/6

\begin{abstract}
The enzymatic degradation of plant biomass is of growing interest for the development of a sustainable bio-based industry. Ascomycete fungi, which degrade complex and recalcitrant plant polymers, secrete enzymes acting on the different components of plant cell wall (cellulose, hemicellulose and lignin). In this study, we present proteomic analyses of enzyme cocktails (secretomes) produced by five strains of Ascomycota (Aspergillus wentii, Aspergillus niger, Aspergillus niger, Neocosmospora haematococca, Penicillium variabile) from different geographical origins. Expert annotation of enzymes secreted revealed a large array of carbohydrate-active enzymes targeting plant cell wall polysaccharides. This study reveals that systematic proteomic analyses of fungal secretomes can contribute to the phenotyping of fungal strains from different geographical origins.
\end{abstract}

Key words - Ascomycete - biomass degradation - cellulase - proteomics - secretomes

\section{Introduction}

The conversion of plant cell wall (i.e. lignocellulose) to monomers or platform polysaccharides has attracted lots of research efforts in the past decades. However, the enzymatic hydrolysis (i.e. saccharification) of lignocellulose still remains a major bottleneck in the biorefinery process due to the recalcitrance of the tight complex formed by cellulose, hemicellulose and lignin within the plant cell wall (Sánchez 2009, Chundawat et al. 2011).

In Nature, filamentous fungi are potent degraders of lignocellulosic biomass as they produce a broad variety of enzymes with different and complementary catalytic activities. Many ascomycete species have been identified as good candidates for the release of monosaccharides. The most extensively used species is Trichoderma reesei, whose wild strain QM6a was originally selected for 
its ability to degrade cotton cellulose. The release of T. reesei QM6a genome revealed a relatively small number and poor diversity of carbohydrate-active enzymes (CAZymes) (Martinez et al. 2008). Other ascomycete genomes have been sequenced such as Neurospora crassa (Galagan et al. 2003), Neocosmospora haematococca (as Nectria haematococca) (Coleman et al. 2009) and many Aspergilli, among which Aspergillus nidulans (Galagan et al. 2005), Aspergillus niger (Pel et al. 2007), Aspergillus oryzae (Machida et al., 2005) and others (see CAZy database; Lombard et al. 2014). Computational analyses revealed large number of genes coding for potential CAZymes, of which numerous have been biochemically characterized and applied in biorefinery processes (van den Brink et al. 2011, Vasu et al. 2012, Yamada et al. 2015, Johansen et al. 2016 ). Although in silico annotations of fungal genomes provide large amounts of information about the genes that encode putative lignocellulose-degrading enzymes, experimental analyses are necessary to better understand complex enzyme mixtures that are secreted (i.e., the secretome) in response to inducers. In this study, we produced secretomes from five ascomycete species and analysed the enzymes secreted by means of proteomic analyses. Expert annotation of proteins secreted revealed a large array of CAZymes targeting plant cell wall polysaccharides.

\section{Materials \& Methods}

\section{Fungal strains}

Identity of fungal strains used in this study (Table 1) was verified by ITS (Internal Transcribed Spacer) sequencing and maintained in the fungal culture collection of the International Centre of Microbial Resources at the French National Institute for Agricultural Research (INRA; Marseille, France). The strains were maintained on MYA2 medium slants (malt extract at $2 \% \mathrm{w} / \mathrm{v}$ and yeast extract at $0.1 \% \mathrm{w} / \mathrm{v})$.

\section{Culture conditions}

Cultures were carried out as described in (Couturier et al. 2012). Briefly, the fungal cultures were grown in a liquid medium containing $15 \mathrm{~g} . \mathrm{l}^{-1}$ autoclaved maize bran (provided by ARD, Pomacle, France) as a carbon source, $2.5 \mathrm{~g} . \mathrm{l}^{-1}$ maltose as a starter, $1.842 \mathrm{~g} . \mathrm{l}^{-1}$ diammonium tartrate, 0.5 g..$^{-1}$ yeast extract, 0.2 g. $.^{-1} \mathrm{KH}_{2} \mathrm{PO}_{4}, 0.0132$ g. $\mathrm{l}^{-1} \mathrm{CaCl}_{2} .2 \mathrm{H}_{2} \mathrm{O}$ and 0.5 g. $\mathrm{l}^{-1} \mathrm{MgSO}_{4} .7 \mathrm{H}_{2} \mathrm{O}$. The sugar content $(\mathrm{w} / \mathrm{w})$ of the autoclaved maize bran fraction was $16.10 \%$ arabinose, $28.73 \%$ xylose, $0.17 \%$ mannose, $5.65 \%$ galactose, and $22.06 \%$ glucose as determined by acidic hydrolysis and liquid chromatography (Bonnin et al. 2001). Fungal cultures were carried out in baffled flasks as described in (Navarro et al. 2014). The cultures were inoculated with $2 \times 10^{5}$ spores. $^{-1}$ prior to incubation at $30^{\circ} \mathrm{C}$ with orbital shaking at $140 \mathrm{rpm}$ (Infors HT, Switzerland).

\section{Secretome preparation}

Cultures were stopped seven days after inoculation. Supernatants (i.e. secretome) were harvested (total volume of 20 to $30 \mathrm{ml}$ ), filtered using $0.2 \mu \mathrm{m}$ polyethersulfone membrane, (Vivaspin, Sartorius), diafiltered with a $10 \mathrm{kDa}$ cut-off polyethersulfone membrane in $50 \mathrm{mM}$ acetate solution buffer, pH 5 (Vivaspin, Sartorius), and concentrated to a final volume of $3 \mathrm{ml}$. Samples were stored at $-20^{\circ} \mathrm{C}$ until use. The total amount of protein was assessed using Bradford assay (Bio-Rad Protein Assay Dye Reagent Concentrate, Ivry, France) with a BSA standard ranging from 0.2 to $1 \mathrm{mg}^{-\mathrm{ml}^{-1}}$.

\section{Proteomic analysis}

Proteins of each secretome $(25 \mu \mathrm{g})$ were separated by one-dimensional (1D) electrophoresis (Precast Tris-Glycine 12\% SDS-PAGE gels, BioRad) and stained with Coomassie blue (BioRad). Each 1D electrophoresis lane was cut into 24 gel fragments $(2 \mathrm{~mm}$ in width) and protein identification was performed using the PAPPSO platform facilities as described in (Couturier et al. 2012). Briefly, in-gel digestion was carried out with the Progest system (Genomic Solution) according to a standard trypsinolysis protocol. Liquid chromatography coupled to tandem mass spectrometry (LC-MS/MS) 
analysis was subsequently performed on an Ultimate 3000 LC system (Dionex) connected to an LTQOrbitrap Discovery mass spectrometer (Thermo Fisher, USA) using a nanoelectrospray ion source.

\section{Protein identification}

The raw mass data were first converted to the mzXML format with the ReAdW software (http://tools.proteomecenter.org/software.php). Protein identification was performed by querying the MS/MS data against the corresponding protein databases along with an in-house contaminant database, using the X!Tandem software (X!Tandem Tornado 2008.02.01.3, http://www.thegpm.org) as described in (Couturier et al. 2012). All the peptides that matched with an E-value lower than 0.05 were parsed with an in-house programme (http:/PAPPSO.inra.fr/bioinformatique.html). Proteins identified by at least two unique peptides and a $\log$ (E-value) lower than 1 .E-8 were considered to be validated.

\section{Functional annotation of CAZymes}

Annotation of the set of CAZymes for each secretome was performed by comparing the predicted proteins to the CAZy database. CAZymes were listed based on the number of representatives of each of the glycoside hydrolases (GH), carbohydrate esterases (CE), polysaccharide lyases (PL), auxiliary activities (AA) and carbohydrate binding modules (CBM) families. For GH5 family, the annotation was performed at the subfamily level (Asperborg et al. 2012).

\section{Results and discussion}

\section{Cultures of Ascomycete strains on maize bran}

Several ascomycete strains (Table 1) were selected in order to identify new promising CAZymes for biomass degradation applications. In particular, the genus Aspergillus has been studied to identify new enzymes of interest and allowed the discovery of novel plant cell wall-active enzymes (Benoit et al. 2015). Accordingly, we selected five ascomycetes strains, including three Aspergilli (A. wentii BRFM 279, A. niger BRFM 131 and A. niger BRFM 442) one Penicillium (P. variabile BRFM 110) and one Neocosmospora (N. haematococca BRFM 1286) from different geographical origins (Table 1).

All strains were able to grow on maize bran with a satisfactory yield of secreted proteins and cultures were harvested at a single time point, i.e. 7 days of growth. Maize bran is a complex and recalcitrant hemicellulosic substrate containing high amount of arabinose and ferulic acid substitutions (Lesage-Meessen et al., 2002). It was previously shown to be a powerful inducer for the secretion of a broad range of CAZymes targeting the plant cell wall, e.g. endo-xylanase, endomannanase, arabinofuranosidase and carbohydrate esterases (Bonnin et al. 2001, Lesage-Meessen et al. 2002, Couturier et al. 2011, Couturier et al. 2012).

\section{Secretion of carbohydrate-active enzymes}

Proteomic analysis using LC-MS/MS is the leading tool for the profiling of fungal secreted proteins (Couturier et al. 2012, Navarro et al. 2014, Poidevin et al. 2014). Here, LC-MS/MS analysis allowed the identification of varying numbers of proteins, ranging from 46 to 159 , in the five strains selected (Table 2).

A. niger BRFM 442 contained the largest set of enzymes, with 159 proteins identified, among which more than half (54\%) were CAZymes. Although P. variabile BRFM 110 secretome contained the smallest set of proteins identified, most of them were CAZymes (76\% of the secreted proteins) thus confirming that maize bran was an inducer adapted to ascomycetes strains for the secretion of CAZymes. Detailed comparison of secreted CAZymes revealed the striking differences between fungal secretomes. Overall, secreted CAZymes were targeting all polysaccharide 
Table 1 Description of the fungal strains used in this study

\begin{tabular}{|c|c|c|c|c|}
\hline Species & Order & Country of origin & $\begin{array}{ll}\text { Strain } & \text { CIRM } \\
\text { number }\end{array}$ & $\begin{array}{l}\text { Equivalent } \\
\text { collection } \\
\text { strain number }\end{array}$ \\
\hline $\begin{array}{l}\text { Aspergillus wentii } \\
\text { (Wehmer) }\end{array}$ & Eurotiales & Belgium & BRFM 279 & MUCL 1049 \\
\hline $\begin{array}{l}\text { Aspergillus niger } \\
\text { (van Tieghem) }\end{array}$ & Eurotiales & Sudan & BRFM 131 & $\begin{array}{l}\text { MUCL } \\
28698\end{array}$ \\
\hline $\begin{array}{l}\text { Aspergillus niger } \\
\text { (van Tieghem) }\end{array}$ & Eurotiales & Bahamas & BRFM 442 & - \\
\hline $\begin{array}{l}\text { Neocosmosporar haematococca } \\
\text { (Berkeley \& Broome; Samuels, Nalim } \\
\text { \& Geiser) }\end{array}$ & Hypocreales & French Guiana & BRFM 1286 & CLL 8012 \\
\hline $\begin{array}{l}\text { Penicillium variabile } \\
\text { (Sopp) }\end{array}$ & Eurotiales & France & BRFM 110 & - \\
\hline
\end{tabular}

Table 2 Distribution of secreted CAZymes identified by means of proteomic analysis. AA. Auxiliary Activity. GH: Glycoside Hydrolase. CE. Carbohydrate Esterase. PL. Polysaccharide Lyase. CBM. Carbohydrate binding Module.

\begin{tabular}{llllll}
\hline & A_went & A_nig & A_nig & $N_{-}$haem & $P_{-}$var \\
& BRFM 279 & BRFM 131 & BRFM 442 & BRFM 1286 & BRFM 110 \\
\hline Non CAZy & 25 & 35 & 72 & 53 & 11 \\
CAZy & 46 & 54 & 86 & 36 & 35 \\
AA & 1 & 1 & 3 & 4 & 0 \\
GH & 42 & 50 & 77 & 30 & 33 \\
CE & 2 & 2 & 5 & 0 & 0 \\
PL & 1 & 1 & 1 & 2 & 2 \\
CBM & 9 & 9 & 14 & 5 & 4 \\
Total & 71 & 89 & 159 & 89 & 46 \\
\hline
\end{tabular}

* CBMs are not included in the total of CAZymes

components of the plant cell wall except the P. variabile BRFM 110 secretome that does not contain any CAZyme targeting hemicellulose (Fig. 1). The secretome of A. niger BRFM 442 displayed a complete set of cellulolytic enzymes comprising GH5 and GH12 endoglucanases, GH6 and GH7 putative cellobiohydrolases (CBH), GH1 and GH3 $\beta$-glucosidases. This rich secretome was the only one to contain AA9 lytic polysaccharide monooxygenase (LPMO) that that were recently identified as boosting factors of biomass degradation (Harris et al. 2010). To a minor extent, the A. niger 131 secretome displayed the major enzymatic components for efficient cellulose conversion, while the other strains, A. wentii BRFM 279, N. haematococca BRFM 1286 and P. variabile BRFM 110, all lacked putative $\mathrm{CBH}$ from GH6 and GH7 families.

The A. niger BRFM 442 displayed the highest diversity of hemicellulose-targeting enzymes with at least one member of (i) xylanases from family GH10 and GH11, (ii) putative arabinofuranosidases from family GH43, GH51 and GH62 and (iii) acetyl esterases from family CE16. The latter were recently shown to be essential for complete xylan depolymerization (Puchart et al. 2015). A. wentii 279 and $N$. haematococca BRFM 1286 produced more representatives of some $\mathrm{GH}$ families. For example, five and three members of the xylan-active GH43 and GH10 families were respectively identified in A. wentii BRFM 279 (Figure 1), illustrating the efficiency of maize bran as inducer of hemicellulases.

Interestingly, the only two secretomes containing pectinases were from the two Aspergillus niger strains BRFM 131 and BRFM 442. This is in line with previous analyses that have reported the potential of Aspergillus for pectin degradation (deVries et al. 2002). 


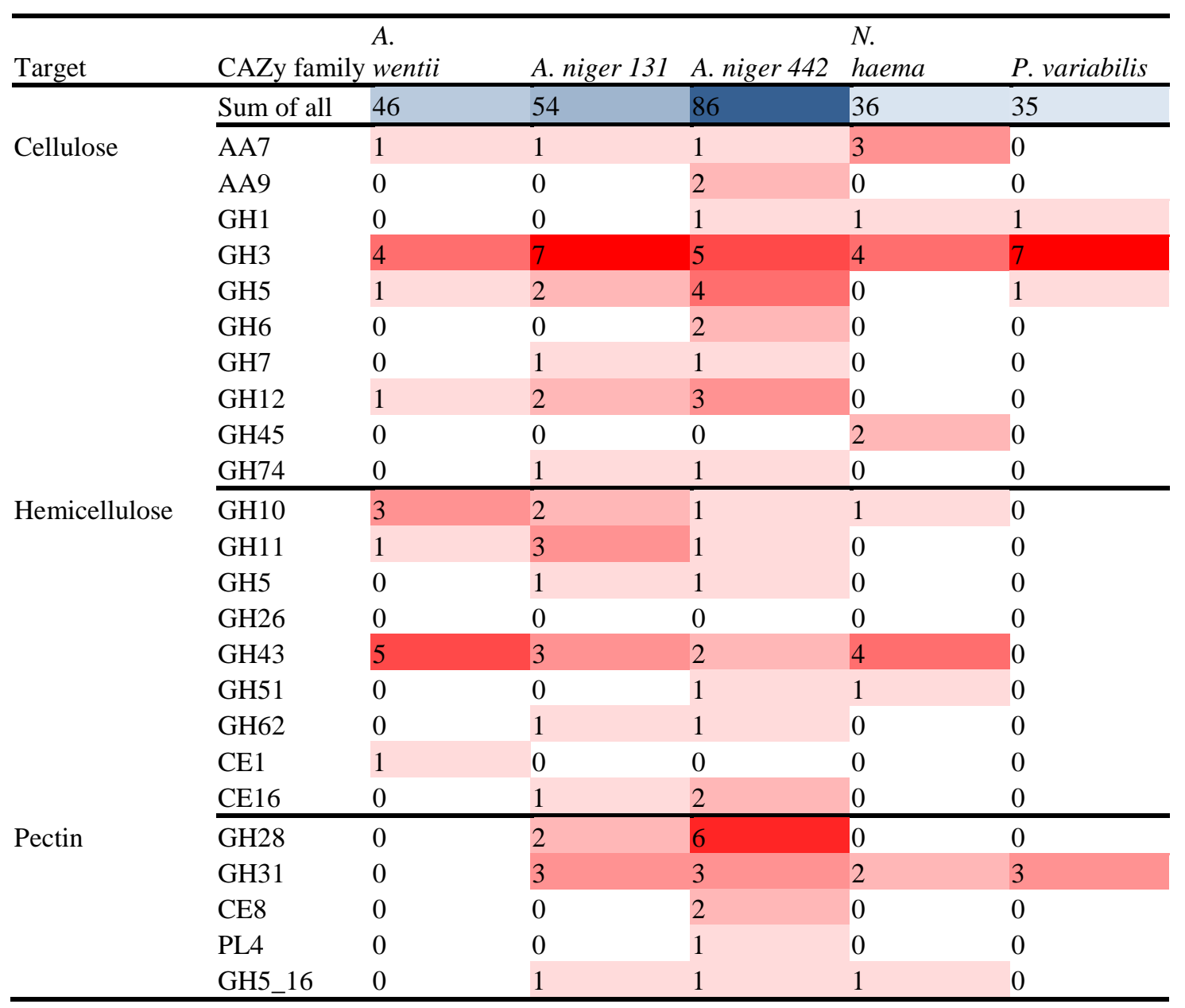

Fig. 1 - Number of representatives for selected CAZy families identified in the studied secretomes. AA. Auxiliary Activity. GH. Glycoside Hydrolase. CE. Carbohydrate Esterase. PL. Polysaccharide Lyase.

The present study illustrates that ascomycetes degrade lignocellulose using very diverse strategies. The number of CAZymes identified highlights the interest in a systematic assessment of fungal biodiversity to improve the enzymatic conversion of lignocellulosic biomass. It enabled the identification of new fungal strains issued from biodiversity with high biotechnological potential. This basic characterization of fungal secretomes will guide the selection of novel CAZymes for further investigation of the substrate specificities. Systematic proteomic analyses of secretomes could contribute to the phenotyping of fungal strains from different geographical origins.

\section{Acknowledgements}

This study was funded by the French National Research Agency (ANR, program E-TRICEL ANR-07-BIOE-006).

\section{References}

Benoit I, Culleton H, Zhou M, DiFalco M, Aguilar-Osorio G, Battaglia E, Bouzid O, Brouwer CP, El-Bushari HB, Coutinho PM, Gruben BS, Hildén KS, Houbraken J, Barboza LA, Levasseur A, Majoor E, Mäkelä MR, Narang HM, Trejo-Aguilar B, van den Brink J, vanKuyk PA, Wiebenga A, McKie V, McCleary B, Tsang A, Henrissat B, de Vries RP. 2015 - Closely related fungi employ diverse enzymatic strategies to degrade plant biomass. Biotechnology for Biofuels 8,107. 
Bonnin E, Brunel M, Gouy Y, Lesage-Meessen L, Asther M, Thibault JF. 2001 - Aspergillus niger I-1472 and Pycnoporus cinnabarinus MUCL39533, selected for the biotransformation of ferulic acid to vanillin, are also able to produce cell wall polysaccharide-degrading enzymes and feruloyl esterases. Enzyme and Microbial Technology 28, 70-80.

CAZy; Carbohydrate-active enzymes database; www.cazy.org

Chundawat SP, Beckham GT, Himmel ME, Dale BE. 2011 - Deconstruction of lignocellulosic biomass to fuels and chemicals. Annual Review of Chemical and Biomolecular Engineering 2, 121-145.

CIRM; « Centre International de Ressources Microbiennes »; https://www6.inra.fr/cirm_eng/Filamentous-Fungi

Coleman JJ, Rounsley SD, Rodriguez-Carres M, Kuo A, Wasmann CC, Grimwood J, Schmutz J, Taga M, White GJ, Zhou S, Schwartz DC, Freitag M, Ma LJ, Danchin EG, Henrissat B, Coutinho PM, Nelson DR, Straney D, Napoli CA, Barker BM, Gribskov M, Rep M, Kroken S, Molnár I, Rensing C, Kennell JC, Zamora J, Farman ML, Selker EU, Salamov A, Shapiro H, Pangilinan J, Lindquist E, Lamers C, Grigoriev IV, Geiser DM, Covert SF, Temporini E, Vanetten HD. 2009 - The genome of Nectria haematococca: contribution of supernumerary chromosomes to gene expansion. PLoS Genetics 5(8):e1000618.

Couturier M, Haon M, Coutinho PM, Henrissat B, Lesage-Meessen L, Berrin JG. 2011 - Podospora anserina hemicellulases potentiate the Trichoderma reesei secretome for saccharification of lignocellulosic biomass. Applied and Environmental Microbiology 77(1), 237-246.

Couturier M, Navarro D, Olivé C, Chevret D, Haon M, Favel A, Lesage-Meessen L, Henrissat B, Coutinho PM, Berrin JG. 2012 - Post-genomic analyses of fungal lignocellulosic biomass degradation reveal the unexpected potential of the plant pathogen Ustilago maydis. BMC Genomics 2, 13:57.

de Vries RP, Jansen J, Aguilar G, Parenicová L, Joosten V, Wülfert F, Benen JA, Visser J. 2002 Expression profiling of pectinolytic genes from Aspergillus niger. FEBS Letters 530(1-3), 41-47.

Galagan JE, Calvo SE, Borkovich KA, Selker EU, Read ND, Jaffe D, FitzHugh W, Ma LJ, Smirnov S, Purcell S, Rehman B, Elkins T, Engels R, Wang S, Nielsen CB, Butler J, Endrizzi M, Qui D, Ianakiev P, Bell-Pedersen D, Nelson MA, Werner-Washburne M, Selitrennikoff CP, Kinsey JA, Braun EL, Zelter A, Schulte U, Kothe GO, Jedd G, Mewes W, Staben C, Marcotte E, Greenberg D, Roy A, Foley K, Naylor J, Stange-Thomann N, Barrett R, Gnerre S, Kamal M, Kamvysselis M, Mauceli E, Bielke C, Rudd S, Frishman D, Krystofova S, Rasmussen C, Metzenberg RL, Perkins DD, Kroken S, Cogoni C, Macino G, Catcheside D, Li W, Pratt RJ, Osmani SA, DeSouza CP, Glass L, Orbach MJ, Berglund JA, Voelker R, Yarden O, Plamann M, Seiler S, Dunlap J, Radford A, Aramayo R, Natvig DO, Alex LA, Mannhaupt G, Ebbole DJ, Freitag M, Paulsen I, Sachs MS, Lander ES, Nusbaum C, Birren B. 2003 - The genome sequence of the filamentous fungus Neurospora crassa. Nature 422(6934), 859-868.

Galagan JE, Calvo SE, Cuomo C, Ma LJ, Wortman JR, Batzoglou S, Lee SI, Baştürkmen M, Spevak CC, Clutterbuck J, Kapitonov V, Jurka J, Scazzocchio C, Farman M, Butler J, Purcell S, Harris S, Braus GH, Draht O, Busch S, D'Enfert C, Bouchier C, Goldman GH, Bell-Pedersen D, Griffiths-Jones S, Doonan JH, Yu J, Vienken K, Pain A, Freitag M, Selker EU, Archer DB, Peñalva MA, Oakley BR, Momany M, Tanaka T, Kumagai T, Asai K, Machida M, Nierman WC, Denning DW, Caddick M, Hynes M, Paoletti M, Fischer R, Miller B, Dyer P, Sachs MS, Osmani SA, Birren BW. 2005 - Sequencing of Aspergillus nidulans and comparative analysis with A. fumigatus and A. oryzae. Nature 438(7071), 1105-1115.

Harris PV, Welner D, McFarland KC, Re E, Navarro Poulsen JC, Brown K, Salbo R, Ding H, Vlasenko E, Merino S, Xu F, Cherry J, Larsen S, Lo Leggio L. 2010 - Stimulation of lignocellulosic biomass hydrolysis by proteins of glycoside hydrolase family 61: structure and function of a large, enigmatic family. Biochemistry 49(15), 3305-3316.

Johansen KS. 2016 - Discovery and industrial applications of lytic polysaccharide mono-oxygenases. Biochemical Society Transactions. 44(1),143-149. 
Lesage-Meessen L, Lomascolo A, Bonnin E, Thibault JF, Buleon A, Roller M, Asther M, Record E, Colonna Ceccaldi B, Asther M. 2002 - A biotechnological process involving filamentous fungi to produce natural crystalline vanillin from maize bran. Applied Biochemistry and Biotechnology 102-103:1-6, 141-153.

Lombard V, Golaconda Ramulu H, Drula E, Coutinho PM, Henrissat B. 2014 - The carbohydrateactive enzymes database (CAZy) in 2013. Nucleic Acids Research D490-5.

Machida M, Asai K, Sano M, Tanaka T, Kumagai T, Terai G, Kusumoto K, Arima T, Akita O, Kashiwagi Y, Abe K, Gomi K, Horiuchi H, Kitamoto K, Kobayashi T, Takeuchi M, Denning DW, Galagan JE, Nierman WC, Yu J, Archer DB, Bennett JW, Bhatnagar D, Cleveland TE, Fedorova ND, Gotoh O, Horikawa H, Hosoyama A, Ichinomiya M, Igarashi R, Iwashita K, Juvvadi PR, Kato M, Kato Y, Kin T, Kokubun A, Maeda H, Maeyama N, Maruyama J, Nagasaki H, Nakajima T, Oda K, Okada K, Paulsen I, Sakamoto K, Sawano T, Takahashi M, Takase K, Terabayashi Y, Wortman JR, Yamada O, Yamagata Y, Anazawa H, Hata Y, Koide Y, Komori T, Koyama Y, Minetoki T, Suharnan S, Tanaka A, Isono K, Kuhara S, Ogasawara N, Kikuchi H. 2005 - Genome sequencing and analysis of Aspergillus oryzae. Nature 438(7071), 1157-1161.

Martinez D, Berka RM, Henrissat B, Saloheimo M, Arvas M, Baker SE, Chapman J, Chertkov O, Coutinho PM, Cullen D, Danchin EG, Grigoriev IV, Harris P, Jackson M, Kubicek CP, Han CS, Ho I, Larrondo LF, de Leon AL, Magnuson JK, Merino S, Misra M, Nelson B, Putnam N, Robbertse B, Salamov AA, Schmoll M, Terry A, Thayer N, Westerholm-Parvinen A, Schoch CL, Yao J, Barabote R, Nelson MA, Detter C, Bruce D, Kuske CR, Xie G, Richardson P, Rokhsar DS, Lucas SM, Rubin EM, Dunn-Coleman N, Ward M, Brettin TS. 2008 Genome sequencing and analysis of the biomass-degrading fungus Trichoderma reesei (syn. Hypocrea jecorina). Nature Biotechnology 26(5), 553-560.

Navarro D, Rosso MN, Haon M, Olivé C, Bonnin E, Lesage-Meessen L, Chevret D, Coutinho PM, Henrissat B, Berrin JG. 2014 - Fast solubilization of recalcitrant cellulosic biomass by the basidiomycete fungus Laetisaria arvalis involves successive secretion of oxidative and hydrolytic enzymes. Biotechnology for Biofuels 7(1),143.

PAPPSO; «Plateforme d'Analyse Protéomique Paris Sud-Ouest »; http://pappso.inra.fr

Pel HJ, de Winde JH, Archer DB, Dyer PS, Hofmann G, Schaap PJ, Turner G, de Vries RP, Albang R, Albermann K, Andersen MR, Bendtsen JD, Benen JA, van den Berg M, Breestraat S, Caddick MX, Contreras R, Cornell M, Coutinho PM, Danchin EG, Debets AJ, Dekker P, van Dijck PW, van Dijk A, Dijkhuizen L, Driessen AJ, d'Enfert C, Geysens S, Goosen C, Groot GS, de Groot PW, Guillemette T, Henrissat B, Herweijer M, van den Hombergh JP, van den Hondel CA, van der Heijden RT, van der Kaaij RM, Klis FM, Kools HJ, Kubicek CP, van Kuyk PA, Lauber J, Lu X, van der Maarel MJ, Meulenberg R, Menke H, Mortimer MA, Nielsen J, Oliver SG, Olsthoorn M, Pal K, van Peij NN, Ram AF, Rinas U, Roubos JA, Sagt CM, Schmoll M, Sun J, Ussery D, Varga J, Vervecken W, van de Vondervoort PJ, Wedler H, Wösten HA, Zeng AP, van Ooyen AJ, Visser J, Stam H. 2007 - Genome sequencing and analysis of the versatile cell factory Aspergillus niger CBS 513.88. Nature Biotechnology 25(2), 221-231.

Poidevin L, Berrin JG, Bennati-Granier C, Levasseur A, Herpoël-Gimbert I, Chevret D, Coutinho PM, Henrissat B, Heiss-Blanquet S, Record E. 2014 - Comparative analyses of Podospora anserina secretomes reveal a large array of lignocellulose-active enzymes. Applied Microbiology and Biotechnoly 98(17),7457-7469.

Puchart V, Berrin JG, Haon M, Biely P. 2015 - A unique CE16 acetyl esterase from Podospora anserina active on polymeric xylan. Applied Microbiol Biotechnol. in press.

Sánchez C. 2009 - Lignocellulosic residues: biodegradation and bioconversion by fungi. Biotechnology Advances 27(2), 185-194.

van den Brink J, de Vries RP 2011 - Fungal enzyme sets for plant polysaccharide degradation. Applied Microbiology and Biotechnology 91(6), 1477-1492. 
Vasu P, Bauer S, Savary BJ. 2012 - Cloning and expression of hemicellulases from Aspergillus nidulans in Pichia pastoris. Methods in Molecular Biology 824, 393-416.

Yamada R, Yoshie T, Sakai S, Wakai S, Asai-Nakashima N, Okazaki F, Ogino C, Hisada H, Tsutsumi H, Hata Y, Kondo A. 2015 - Effective saccharification of kraft pulp by using a cellulase cocktail prepared from genetically engineered Aspergillus oryzae. Bioscience, Biotechnology and Biochemistry 79(6), 1034-1037. 